\title{
High-resolution mapping of the quantitative trait locus (QTLs) conferring resistance to false smut disease in rice
}

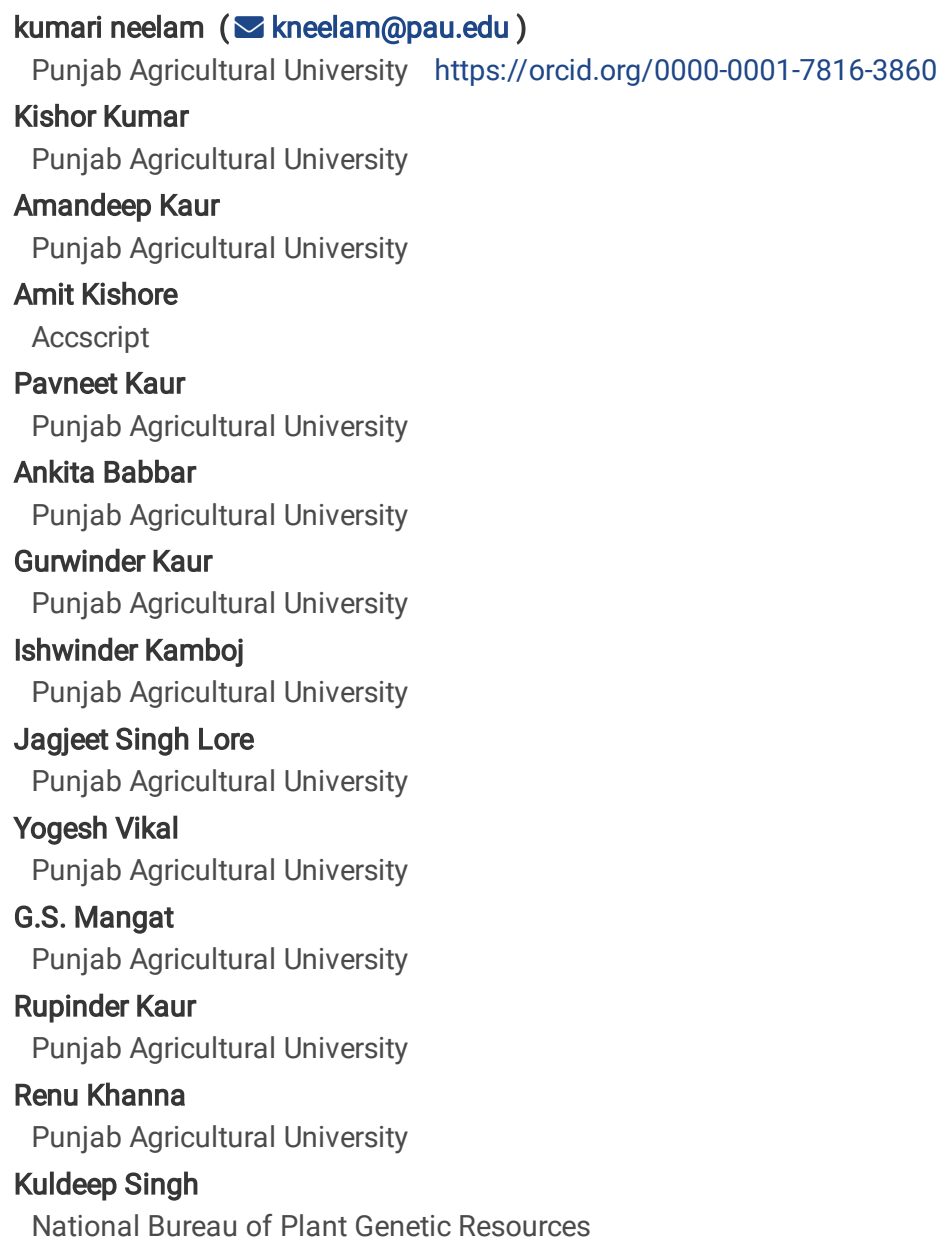

\section{Research Article}

Keywords: Rice false smut, Ustilaginoidea virens, QTL mapping, R genes, NBS-LRR domain-containing protein, Marker-assisted selection, Map-based cloning

Posted Date: March 22nd, 2021

DOI: https://doi.org/10.21203/rs.3.rs-325960/v1

License: (c) (i) This work is licensed under a Creative Commons Attribution 4.0 International License. Read Full License

Version of Record: A version of this preprint was published at Journal of Applied Genetics on September 17th, 2021. See the published version at https://doi.org/10.1007/s13353-021-00659-8. 


\section{Abstract}

Decoding the genetic mechanisms underlying disease resistance is of great importance for crop improvement. Rice false smut (RFS) is a major fungal disease caused by Ustilaginoidea virens that hampers the grain quality and yield of rice worldwide. It causes $2.8-49 \%$ global yield loss depending upon disease severity and varieties grown. In India, the severity of yield loss ranged from $2-75 \%$. Keeping the economic importance of this disease, identification of the genes/QTLs governing disease resistance is of prime importance for the development of the linked markers and cloning of the genes. Here, we report mapping of QTLs using a recombinant inbred line (RIL) population derived from a cross between resistant line, RYT2668, and a highly susceptible variety, PR116. The population was evaluated for rice false smut disease under field conditions for three cropping seasons 2013 , 2015, and 2016. A total of seven QTLs were mapped on rice chromosomes 2, 4, 5, 7, and 9 of rice using 2326 single nucleotide polymorphism (SNP) markers. Among them, a novel QTL qRFSr9.1 affecting total smut ball (TSB)/panicle on chromosome 9 exhibited the largest phenotypic effect. The prediction of putative candidate genes within the qRFSr9. 1 spanned in $994.1 \mathrm{~Kb}$ revealed four NBS-LRR domain-containing disease resistance proteins. We identified SNPs/Indels associated with the disease resistance which could be used for accelerating breeding programs using marker-assisted selection. In summary, our findings mark the 'hot-spot' region on rice chromosomes along with the identification of disease resistance genes in conferring resistance to the rice false smut disease.

\section{Introduction}

Rice false smut (RFS) is an economically important grain disease caused by the fungus Ustilaginoidea virens (Cooke) Takahashi. It is not only threatening rice productivity but also impairs grain quality in most of the rice-growing countries, every year (Fan et al. 2016; Qiu et al. 2019). Depending upon the severity of disease and the variety grown, RFS causes 2.8-49\% yield loss (Kumari and Kumar 2015; Andargie et al. 2018). In India, yield loss due to false smut was varied from 2-75\% (Ladhalakshmi et al. 2012). Previously, RFS was considered a minor disease due to sporadic occurrence (Zhang et al. 2014; Jiehua et al. 2019). Recently, it is emerged as a major constraint to the global rice production due to the adaptation of susceptible high yielding rice cultivars and hybrids, heavy application of nitrogenous fertilizers, and climate change (Rush et al. 2000; Ladhalakshmi et al. 2012). RFS primarily infects rice panicle at the booting stage and inhibits fertilization. Subsequently, it leads to a considerable number of infertile spikelets and poor seeds (Tang et al. 2013; Fan et al. 2015). Upon successful infection, RFS produces white, ball-shaped mycelium. Later, it develops into large velvety green smut balls during the maturation of grains (Zhang et al. 2014). The yield loss occurs primarily due to grain chaffiness, reduction in test weight, and sterility of spikelets (Ladhalakshmi et al. 2012). RFS not only causes a significant reduction in the grain yield and grain quality but also produces two potentially harmful mycotoxins (Koiso et al. 1994; Shan et al. 2012). Consumption of rice grains contaminated with these fungal mycotoxins cause a poisonous effect on animals and humans (Ludueña et al. 1994; Nakamura et al. 1994; Li et al. 1995). Hence, RFS is gaining attention among pathologists, breeders, and farmers.

The management of false smut disease is very tedious as its severity is highly influenced by environmental conditions (Fan et al. 2016). At present, management practices for the false smut disease include chemical control, cultivation practices, and host resistance. Most of the chemical measures are ineffective against rice false smut disease because when smut balls appear, the crop is already at the maturation stage (Yang et al. 2014). The fungicide application greatly increases the production cost and their repeated use may cause potential risks to the environment and human health, particularly if residues persist in soil and crop harvest. Moreover, excessive use of fungicides also increases the risk of the emergence of resistant pathotypes (Brooks et al. 2009). Cultivation practices, such as the use of conservation tillage, furrow irrigation along with moderate nitrogen and other fertilizers applications might be helpful in reducing the disease pressure on the susceptible rice cultivars but the increased cost and other problems related to the agronomic practices masks the overall benefits.

Breeding rice cultivars with a high level of resistance to false smut is one of the effective, environment-friendly, economic, and sustainable approaches to control this disease (Wang et al. 2019). In the last few decades, several reports were published on screening and identification of rice germplasm resistance to rice false smut (Pannu et al. 2010; Ashizawa et al. 2012; Lore et al. 2013; Rani et al. 2016; Kaur et al. 2018; Chaudhari et al. 2019) but, limited information regarding genes/QTLs conferring the false smut resistance is available on the public domain (Ke et al. 2017, Li et al. 2008; Zhou et al. 2014; Andargie et al. 2018). Ten false smut resistance quantitative trait loci were mapped from Lemont, and four of them showed larger and consistent effect across two seasons (Zhou et al. 2014). Rice false smut resistance genes in IR28 were shown to control by two major genes and multiple minor genes based on the mixed model of major gene and polygene inheritance (Li et al. 2008; Li et al. 2011). Later, two major QTLs responsible for rice false smut in IR28 were mapped on chromosome 5 using the classical genetic mapping approach (Andargie et al. 2018). Recently, five QTLs associated with RFS resistance were mapped on chromosomes 2, 4, 8 and 11 using a RIL population derived from a cross between RFS resistant rice cultivar MR183-2 and highly susceptible rice cultivar 08R2394. Among these, qFSr8-1 accounted larger phenotypic variance (Han et al. 2020). Recent progress also suggested that resistance genes (R genes) are responsible for conferring resistance to false smut (Han et al. 2020; Qiu et al. 2020). A novel false smut resistance gene FSR1 encoding a DNA methylase 2 (DNMT2) from Nanjing11 on long arm of chromosome 1 was identified (Qiu et al. 2020). Based on the above cited facts, it can be concluded that only sparse information is available on the genes/ QTLs governing this disease that too using limited resistant parents. Till date, no resistance QTLs/genes have been fine mapped or cloned indicating the urgency of the identification of new sources of resistance along with the future research on deciphering the molecular mechanism behind disease resistance is required.

The objective of this research was to identify the QTLs conferring false smut resistance in a breeding line RYT2668 displaying a high level of resistance using SNP-based high-density linkage map. The research contributes to the knowledge towards the role of nucleotide binding sites (NBS) domain- 
containing disease resistance protein in conferring resistance to the false smut disease of rice.

\section{Materials And Methods}

Plant materials and mapping population

A mapping population comprising 250 recombinant inbred lines (RILs, $F_{9}$ ) was developed from a cross between RFS resistant breeding line 'RYT2668' with pedigree PAU2962-89-1-3-3 (Pusa44/PR109) and a highly susceptible Indica cultivars PR116 (Punjab Rice 116). The $\mathrm{F}_{1}$ individual was selfed up to nine generations to produce recombinant inbred lines (RILs) by single-seed descent method. From this mapping population, a set of 94 RILs were randomly selected for the QTL mapping.

Preparation of pure culture

The fungal inoculum comprises the bulk of mycelium of $U$. virens widespread in Northwestern plains of India. For preparing pure culture, smut balls originated in heavily infected panicles from previous season crop grown at hotspot zone were collected. Smut balls were washed thoroughly in distilled water and cultured on potato sucrose agar (PSA) medium. The culture was incubated at $25 \pm 2{ }^{\circ} \mathrm{C}$. The pure culture was obtained by streaking single colony. Fungal inoculum was prepared in potato sucrose broth (PSB). The concentration of the inoculum was adjusted at $7.5 \times 10^{5} \mathrm{conidia} / \mathrm{mL}$.

\section{Evaluations of resistance to $U$. virens}

The RIL population including resistant parent RYT2668 and susceptible parent PR116 were evaluated against rice false smut at Punjab Agricultural University (PAU), Ludhiana, Punjab, India in 2013, 2015 and 2016 under wetland field conditions. In the crop season 2016, the population was evaluated in two locations, Ludhiana and Kapurthala, Punjab, India (false smut hotspot region). The data of crop season 2016 comprises the mean of both locations. The RIL population and parents were planted in a completely randomized block design with plant-to-plant and row-to-row distance of $15 \times 20$ $\mathrm{cm}$ in three replications in each year. The crop was raised following the standard package of practices as recommended by PAU. The fungal inoculum was sprayed at the early flowering stage using a hand sprayer. The data were observed at the grain hardening stage. Five plants of each RIL population were tagged for observation. During each season, data on total smut balls per panicles, number of infected panicles per plant, sterility percentage and visual score were observed and averaged for mapping. For calculation of visual score, $0-9$ scale was adopted given by standard evaluation system of rice (IRRI, 2002) where $0=$ no incident, $1=<1 \%$ infected florets, $3=1-5 \%$ infected florets, $5=6-25 \%$ infected florets, $7=26-50 \%$ infected florets and $9=$ $51-100 \%$ infected florets.

DNA extraction and SNP genotyping

Genomic DNA was extracted from fresh leaves of 25 to 30 days old field grown RIL population and parental lines using large-scale DNA extraction protocol. DNA was quantified using a spectrophotometer (Eppendorf Biophotometer) and normalized by adding 1X Tris EDTA (TE) buffer. The quality and integrity were also checked by resolving the genomic DNA on $0.8 \%$ Agarose gel. The genomic DNA samples ( $1 \mu \mathrm{g}$ each) of the RIL population and parents were outsourced to SciGenom (www.scigenom.com) for SNP genotyping. The genotyping was done by double-digest restriction site-associated DNA sequencing (ddRAD-seq) through double digestion of the samples using two enzymes Sph/ and Mlucl. The genomic DNA was sequenced using the Illumina HiSeq 2000/2500 sequencing platform and SNPs were identified by aligning the reads with the reference sequence using Bowtie2. SNPs were called using SAM tools program (Version 0.1.18). SNP call rate within a locus $\geq 0.7$ and minor allele frequency (MAF) $\geq 0.05$ were kept as threshold for filtering raw SNP data. Approximately, 100-120 MB data per sample was obtained for further analysis.

Linkage mapping

A high-density linkage map for all chromosomes was constructed using MapDisto 1.8.2.1 program (Lorieux 2012). SNP markers showing the expected segregation ratio were included based on the chi-square test. SNPs exhibiting segregation distortion or $\chi 2>10$ were excluded from the analysis. SNP markers with more than $10 \%$ missing data were also removed from the analysis. Finally, high-quality SNP markers were used for the construction of a genetic map. The markers were ordered using the Kosambi mapping function. The maximum gaps and LOD (logarithm of odds) were kept at $25 \mathrm{cM}$ and 3, respectively. The best plausible order of each linkage group was obtained following the commands 'order sequence,' 'check inversions,' 'ripple order,' and 'drop locus'. Linkage groups (LGs) were plotted using MapChart V2.32 (Voorrips 2002).

\section{QTL mapping}

The mean values of infected panicle per plant, total smut balls per panicle and score observed in 2013, 2015 and 2016 were used for QTL analysis. The composite interval mapping (CIM) function of winQTL cartographer version 2.5 software (Wang et al. 2011) was used for mapping QTL(s) for RFS resistance QTLs. The stepwise threshold LOD scores for declaring the significance of the QTLs was calculated based on 1000 iterations at $P \leq 0.05$ (Churchill and Doerge 1994). Markers used as cofactors in the CIM model were selected by forward and backward regression analyses with a window size of $10 \mathrm{cM}$ and walking speed $1 \mathrm{cM}$. The proportion of observed phenotypic variance attributable to the QTL was estimated by the coefficient of determination $\left(R^{2}\right)$ using maximum likelihood for composite interval mapping.

Analysis of open reading frames (ORFs) in the QTL region 
The physical positions, size of the QTLs, and number of ORFs in the QTL region were determined by searching physical position of the QTL-associated flanking SNPs in the Nipponbare reference-IRGSP-1.0 pseudomolecule available at Rice Genome Annotation Project database (http://rice.plantbiology.msu.edu/). The putative ORFs were retrieved and analyzed that are present within the QTL region.

\section{Results}

Inheritance of false smut resistance in RIL population

The RYT2668 (resistant) and PR116 (susceptible) parents showed contrasting responses to false smut disease for all the three seasons (Fig. 1, Supplementary table 5). The mean data of the crop season 2013, 2015, and 2016 was used for QTL analysis (Table 1). The mean of the IP/plant observed for the parental line RYT2668 and PR116 was 2.84 and 32.17, respectively. The mean IP/plant on the RIL population was ranged from 036.54. The mean of the TSB/panicles was 1.3 and 9.9 for the RYT2668 and PR116, respectively. The mean TSB/panicle on the RIL population was ranged from 0-26.44. Similarly, the mean score observed for the RYT2668 and PR116 was 1.6 and 7.0, respectively. The mean score on RIL population ranged from 0-5.44. 
Table 1

Mean phenotypic data of the RIL population for the false smut disease components

\begin{tabular}{|c|c|c|c|c|c|c|c|c|c|}
\hline S. No. & RILs & IP/plant ${ }^{a}$ & TSB/panicle & Score & S. No. & RILs & IP/plant & TSB/panicle & Score \\
\hline 1 & RIL-1 & $7.4 \pm 7.2$ & $4.3 \pm 5.1$ & $1.8 \pm 2$ & 49 & RIL-107 & $13 \pm 9.1$ & $5.4 \pm 5.7$ & $2 \pm 1.6$ \\
\hline 2 & RIL-2 & $8.7 \pm 7.8$ & $6.7 \pm 7.6$ & $2.1 \pm 1.8$ & 50 & RIL-109 & $11 \pm 6.8$ & $5.7 \pm 3.3$ & $3.2 \pm 1.8$ \\
\hline 3 & RIL-6 & $3.3 \pm 4.1$ & $1.2 \pm 1.5$ & $1.2 \pm 1.5$ & 51 & RIL-111 & $21.7 \pm 13.5$ & $10.2 \pm 7.1$ & $3.6 \pm 2.3$ \\
\hline 4 & RIL-7 & $11.1 \pm 12.3$ & $2.7 \pm 3.1$ & $1.6 \pm 1.3$ & 52 & RIL-115 & $9 \pm 4.9$ & $2.9 \pm 2.5$ & $1.4 \pm 1.2$ \\
\hline 5 & RIL-9 & $5.2 \pm 6.4$ & $3.3 \pm 4.1$ & $1.2 \pm 1.5$ & 53 & RIL-119 & $21.6 \pm 9.4$ & $8 \pm 3.9$ & $3.2 \pm 1.2$ \\
\hline 6 & RIL-10 & $2.8 \pm 3.4$ & $1.6 \pm 1.9$ & $0.9 \pm 1.1$ & 54 & RIL-120 & $13 \pm 5.2$ & $5.8 \pm 3.2$ & $3 \pm 1.4$ \\
\hline 7 & RIL-13 & $5 \pm 6.1$ & $1.4 \pm 1.8$ & $1 \pm 1.2$ & 55 & RIL-127 & $4.1 \pm 5$ & $1.6 \pm 1.9$ & $1 \pm 1.2$ \\
\hline 8 & RIL-14 & $30.7 \pm 8.6$ & $23.8 \pm 6.9$ & $5.4 \pm 1.5$ & 56 & RIL-130 & $6.9 \pm 8.5$ & $2.2 \pm 2.7$ & $1.2 \pm 1.5$ \\
\hline 9 & RIL-17 & $17 \pm 9.5$ & $7.8 \pm 4$ & $3.2 \pm 1.9$ & 57 & RIL-136 & $7.9 \pm 9.7$ & $5.7 \pm 6.9$ & $1.2 \pm 1.5$ \\
\hline 10 & RIL-18 & $27.9 \pm 11.7$ & $19.8 \pm 10$ & $4.2 \pm 2.3$ & 58 & RIL-140 & $22.1 \pm 10.3$ & $16.6 \pm 5.4$ & $4.6 \pm 1.7$ \\
\hline 11 & RIL-19 & $19.4 \pm 12.3$ & $8 \pm 6$ & $3.6 \pm 2.2$ & 59 & RIL-142 & $16.1 \pm 7.3$ & $4.3 \pm 2.5$ & $2.8 \pm 1.7$ \\
\hline 12 & RIL-20 & $22.7 \pm 12.5$ & $7 \pm 5.3$ & $3.3 \pm 2.5$ & 60 & RIL-144 & $1.9 \pm 2.3$ & $0.7 \pm 0.8$ & $0.3 \pm 0.4$ \\
\hline 13 & RIL-21 & $17.5 \pm 10.9$ & $7.9 \pm 5.3$ & $2.9 \pm 2$ & 61 & RIL-154 & $3.2 \pm 3.2$ & $1 \pm 1$ & $0.8 \pm 0.8$ \\
\hline 14 & RIL-23 & $14.3 \pm 11.1$ & $9.2 \pm 11.1$ & $2 \pm 1.9$ & 62 & RIL-155 & $8.9 \pm 8.6$ & $4.9 \pm 5.6$ & $2.1 \pm 2.2$ \\
\hline 15 & RIL-24 & $25.6 \pm 12.8$ & $19.4 \pm 13.8$ & $3.8 \pm 2.3$ & 63 & RIL-158 & $1.2 \pm 0.8$ & $0.4 \pm 0.4$ & $0.4 \pm 0.4$ \\
\hline 16 & RIL-25 & $6.9 \pm 8.4$ & $0.8 \pm 1$ & $0.8 \pm 1$ & 64 & RIL-160 & $6.2 \pm 6.5$ & $2.8 \pm 3.2$ & $1.3 \pm 1.1$ \\
\hline 17 & RIL-26 & $14.3 \pm 8.7$ & $20.6 \pm 9.7$ & $3.2 \pm 1.4$ & 65 & RIL-162 & $14.8 \pm 7.6$ & $7.2 \pm 4.5$ & $3.2 \pm 2$ \\
\hline 18 & RIL-27 & $14.4 \pm 7.5$ & $7.8 \pm 4.6$ & $3 \pm 1.7$ & 66 & RIL-164 & $9.3 \pm 7.4$ & $2.6 \pm 2.7$ & $1.7 \pm 0.9$ \\
\hline 19 & RIL-29 & $18 \pm 10$ & $6.2 \pm 3.9$ & $3 \pm 2.2$ & 67 & RIL-170 & $3.6 \pm 2.3$ & $0.9 \pm 0.9$ & $1.2 \pm 0.8$ \\
\hline 20 & RIL-30 & $22.4 \pm 12.7$ & $10.7 \pm 7.1$ & $3.1 \pm 2$ & 68 & RIL-174 & $23.8 \pm 15.5$ & $12 \pm 8.6$ & $3.3 \pm 2.2$ \\
\hline 21 & RIL-31 & $16.3 \pm 11$ & $7.3 \pm 6.5$ & $2.4 \pm 2.4$ & 69 & RIL-182 & $23.8 \pm 8.2$ & $17 \pm 8.8$ & $4 \pm 1$ \\
\hline 22 & RIL-35 & $14.7 \pm 11.5$ & $4.3 \pm 3.2$ & $2.9 \pm 2$ & 70 & RIL-185 & $14.7 \pm 1.5$ & $4.6 \pm 1.6$ & $3.4 \pm 0.7$ \\
\hline 23 & RIL-36 & $8.9 \pm 9.7$ & $3.8 \pm 4$ & $1.8 \pm 2$ & 71 & RIL-186 & $21.7 \pm 7.1$ & $7.1 \pm 2.9$ & $3.8 \pm 1.1$ \\
\hline 24 & RIL-37 & $26.8 \pm 13$ & $16.8 \pm 7.4$ & $4.4 \pm 1.7$ & 72 & RIL-187 & $20.7 \pm 4$ & $7.8 \pm 1.9$ & $3.4 \pm 1$ \\
\hline 25 & RIL-44 & $10 \pm 4.1$ & $4.3 \pm 3.2$ & $1.7 \pm 0.6$ & 73 & RIL-188 & $36.5 \pm 10.1$ & $24.2 \pm 11.8$ & $5.2 \pm 1.4$ \\
\hline 26 & RIL-47 & $2.7 \pm 2.3$ & $0.4 \pm 0.4$ & $0.6 \pm 0.4$ & 74 & RIL-190 & $14.3 \pm 8.9$ & $4.2 \pm 3.1$ & $2.7 \pm 1.8$ \\
\hline 27 & RIL-48 & $6.4 \pm 7.8$ & $2.3 \pm 2.9$ & $0.8 \pm 1$ & 75 & RIL-192 & $19.4 \pm 8.9$ & $8.7 \pm 4$ & $3.6 \pm 1.7$ \\
\hline 28 & RIL-50 & $14.7 \pm 10.3$ & $5 \pm 5.5$ & $1.3 \pm 1.4$ & 76 & RIL-193 & $3.7 \pm 3.1$ & $0.9 \pm 0.9$ & $1.3 \pm 0.8$ \\
\hline 29 & RIL-53 & $3 \pm 2.3$ & $0.3 \pm 0.2$ & $0.6 \pm 0.4$ & 77 & RIL-195 & $32.8 \pm 11.8$ & $19.8 \pm 11.5$ & $4.9 \pm 2.6$ \\
\hline 30 & RIL-55 & $1.3 \pm 1.3$ & $0.2 \pm 0.2$ & $0.5 \pm 0.5$ & 78 & RIL-205 & $2.2 \pm 1.4$ & $0.6 \pm 0.5$ & $0.6 \pm 0.5$ \\
\hline 31 & RIL-59 & $20.1 \pm 11.8$ & $14 \pm 11.4$ & $3.8 \pm 1.1$ & 79 & RIL-206 & $21.8 \pm 2.4$ & $10.7 \pm 2.9$ & $3.7 \pm 0.9$ \\
\hline 32 & RIL-61 & $29.8 \pm 10.5$ & $14.7 \pm 12.5$ & $3.9 \pm 2.2$ & 80 & RIL-212 & $4.1 \pm 5$ & $0.9 \pm 1.1$ & $0.4 \pm 0.5$ \\
\hline 33 & RIL-66 & $20.4 \pm 11.1$ & $9.4 \pm 5.6$ & $3.2 \pm 2.1$ & 81 & RIL-216 & $12.1 \pm 4.4$ & $4.1 \pm 2.5$ & $2.3 \pm 0.9$ \\
\hline 34 & RIL-67 & $0 \pm 0$ & $0 \pm 0$ & $0 \pm 0$ & 82 & RIL-219 & $4.9 \pm 4.8$ & $1 \pm 1$ & $1.1 \pm 0.8$ \\
\hline 35 & RIL-68 & $16.9 \pm 5.4$ & $5.9 \pm 2.4$ & $2.7 \pm 1.3$ & 83 & RIL-221 & $14.2 \pm 7.7$ & $7.7 \pm 5.7$ & $2.9 \pm 1.2$ \\
\hline 36 & RIL-70 & $18.9 \pm 5.8$ & $9.1 \pm 3.8$ & $3.6 \pm 1.3$ & 84 & RIL-222 & $24 \pm 13.4$ & $8.7 \pm 4.3$ & $4.3 \pm 2$ \\
\hline 37 & RIL-71 & $8.5 \pm 9.3$ & $3.4 \pm 4$ & $1.1 \pm 0.8$ & 85 & RIL-223 & $19.4 \pm 11.4$ & $7.8 \pm 4.9$ & $3.2 \pm 1.5$ \\
\hline
\end{tabular}

a Infected panicle/plant

b Total smut balls/panicle 


\begin{tabular}{|llllllllll|}
\hline S. No. & RILs & IP/plant $^{\text {a }}$ & TSB/panicle & Score & S. No. & RILs & IP/plant & TSB/panicle & Score \\
\hline 38 & RIL-73 & $17.4 \pm 11.6$ & $5.6 \pm 3.2$ & $2.6 \pm 1.4$ & 86 & RIL-224 & $32.9 \pm 10.1$ & $26.4 \pm 11.6$ & $4.8 \pm 2.6$ \\
\hline 39 & RIL-75 & $33.5 \pm 7.9$ & $13.1 \pm 5$ & $5 \pm 1.2$ & 87 & RIL-229 & $16.3 \pm 3.8$ & $6.9 \pm 1.9$ & $3.2 \pm 0.7$ \\
\hline 40 & RIL-79 & $23 \pm 12.7$ & $12.1 \pm 8.3$ & $3.5 \pm 2$ & 88 & RIL-230 & $9.9 \pm 9.5$ & $2.8 \pm 2.8$ & $1.4 \pm 1$ \\
\hline 41 & RIL-80 & $5 \pm 4.8$ & $1.6 \pm 1.7$ & $0.8 \pm 0.5$ & 89 & RIL-234 & $11.8 \pm 7.8$ & $4.6 \pm 3.6$ & $2.7 \pm 1.5$ \\
\hline 42 & RIL-85 & $10.7 \pm 13.1$ & $7 \pm 8.6$ & $1.4 \pm 1.8$ & 90 & RIL-236 & $4.3 \pm 4.3$ & $0.9 \pm 0.9$ & $1.1 \pm 0.8$ \\
\hline 43 & RIL-87 & $17.1 \pm 6.7$ & $6.3 \pm 3.7$ & $3 \pm 1.6$ & 91 & RIL-238 & $17.5 \pm 9.6$ & $7 \pm 5.1$ & $2.2 \pm 1.4$ \\
\hline 44 & RIL-89 & $7.2 \pm 7.3$ & $1.6 \pm 1.7$ & $1.3 \pm 1.1$ & 92 & RIL-240 & $17.4 \pm 7.7$ & $7.8 \pm 2$ & $4 \pm 1.5$ \\
\hline 45 & RIL-92 & $3.7 \pm 4.5$ & $0.4 \pm 0.5$ & $0.4 \pm 0.5$ & 93 & RIL-248 & $25.8 \pm 10.9$ & $13.8 \pm 6.2$ & $4.6 \pm 1.5$ \\
\hline 46 & RIL-93 & $4.1 \pm 5$ & $2.4 \pm 3$ & $0.9 \pm 1.1$ & 94 & RIL-249 & $20.1 \pm 8.4$ & $9.2 \pm 4.2$ & $1.9 \pm 0.6$ \\
\hline 47 & RIL-97 & $24.6 \pm 7.6$ & $20.4 \pm 9.8$ & $4.8 \pm 1.5$ & 95 & RYT 2668 & $2.8 \pm 0.7$ & $1.3 \pm 1.3$ & $1.6 \pm 0.9$ \\
\hline 48 & RIL-101 & $7.4 \pm 7.5$ & $3.2 \pm 3.7$ & $1.6 \pm 1.3$ & 96 & PR116 & $32.2 \pm 13$ & $9.9 \pm 5.0$ & $7.0 \pm 1.2$ \\
\hline a Infected panicle/plant & & & & & & & & \\
\hline b Total smut balls/panicle & & & & & & \\
\hline
\end{tabular}

High-density linkage mapping

A total of 3348 polymorphic SNP markers were obtained between the two parents (Table 2). After removal of distorted markers, a total of 2983 SNP markers were used for the construction of the linkage map. We kept only one representative marker from the set of co-segregating markers showing identical segregation patterns in the linkage analysis. Finally, a high-density linkage map was prepared from a set of 2326 high-quality singleton SNPs markers and assigned them on all 12 linkage groups (LGs) of rice (Supplementary table 1). The total genetic length of all the linkage groups was $2081.5 \mathrm{cM}$ with an average of 1.11 SNPs per cM across the genome (Supplementary Fig. 1, Supplementary table 2). The genetic length of smallest LG was $46.871 \mathrm{cM}$ for Chromosome 12 (Chr12) whereas the largest linkage group was chromosome 2 (Chr02) with $388.266 \mathrm{cM}$ (Table 2).

Table 2

Distribution of SNP markers on 12 chromosomes of rice

\begin{tabular}{|c|c|c|c|c|c|}
\hline $\begin{array}{l}\text { Linkage } \\
\text { groups (LG) }\end{array}$ & $\begin{array}{l}\text { Total No. of polymorphic } \\
\text { SNP markers }\end{array}$ & $\begin{array}{l}\text { Polymorphic SNP markers used for } \\
\text { linkage mapping }\end{array}$ & $\begin{array}{l}\text { Singleton } \\
\text { SNP }\end{array}$ & $\begin{array}{l}\text { Length of genetic } \\
\text { map (cM) }\end{array}$ & $\begin{array}{l}\text { Average } \\
\text { markers/ } \\
\mathrm{cM}\end{array}$ \\
\hline Chr01 & 441 & 372 & 274 & 191.378 & 1.43 \\
\hline ChrO2 & 380 & 348 & 291 & 328.266 & 0.88 \\
\hline Chr03 & 521 & 479 & 427 & 272.009 & 1.56 \\
\hline ChrO4 & 189 & 169 & 142 & 128.373 & 1.10 \\
\hline Chr05 & 163 & 158 & 112 & 143.479 & 0.78 \\
\hline Chr06 & 409 & 369 & 295 & 218.815 & 1.34 \\
\hline Chr07 & 182 & 159 & 131 & 162.380 & 0.80 \\
\hline Chr08 & 155 & 145 & 107 & 108.950 & 0.98 \\
\hline Chr09 & 263 & 233 & 103 & 120.550 & 0.85 \\
\hline Chr10 & 128 & 105 & 85 & 69.594 & 1.22 \\
\hline Chr11 & 411 & 355 & 293 & 291.294 & 1.00 \\
\hline Chr12 & 106 & 91 & 66 & 46.871 & 1.40 \\
\hline Total & 3348 & 2983 & 2326 & 2081.959 & 1.11 (mean) \\
\hline
\end{tabular}

QTL identification

QTL analysis with IP/plant, TSB/panicle, and score detected a total of seven QTLs on chromosomes 2, 4, 5, 7, and 9 controlling rice false smut disease (Table 3). Two QTLs (tentatively designated as qRFSr5.3 and qRFSr7.1) were detected for the IP/plant on chromosome 5 and 7. The qRFSr5.3 was located on chromosome 5 between SNP markers C5.4852660 and C5.4888145 at LOD score 3.3 explaining $9.3 \%$ phenotypic variance. Whereas, qRFSr7. 1 was mapped between SNP markers C7.13373853 and C7.13369043 at 3.2 LOD score with $8.9 \%$ phenotypic variance. Genomic region of the 
locus qRFSr7.1 was fairly close to another QTL qRFSr7.2 detected on same chromosome for score. A single QTL qRFSr9.1 was detected for TSB/plant on chromosome 9 between SNP markers C9.8029326 and C9.9023440 at LOD score 6.2 exhibiting 20.6\% phenotypic variance. Four QTLs (designated as qRFSr2.2, qRFSr4.3, qRFSr5.4, and qRFSr7.2) were detected for score on chromosome 2, 4, 5, and 7. The QTL qRFSr2.2 was detected on chromosome 2 between two SNP markers C2.33882274 and C2.33796392 at 3.9 LOD score explaining 11.0\% phenotypic variance. The qRFSr4.3 was mapped on chromosome 4 between C4.31529767 and C4.31393008 at LOD scores 3.5 displaying 8.9\% phenotypic variance. The QTL qRFSr5.4 was detected between two SNP markers C5.1021716 and C5.2489245 on chromosome 5 at 3.0 LOD score explaining $8.0 \%$ phenotypic variance. The qRFSr7.2 was detected on chromosome 7 between two SNP markers C7.13373853 and C5.13369043 at LOD scores 5.1 accounting for $14.2 \%$ phenotypic variance. The phenotypic variance conferred by $q R F S r 2.2$, qRFSr5.3, and qRFSr5.4 had a negative additive effect indicating that the resistance conditioned in progenies was contributed by the alleles from susceptible parent PR116. Three QTLs qRFSr2.2, qRFSr7.2, and qRFSr9.1 were identified as major QTLs exhibiting larger effect on the traits whereas the remaining four QTLs were accounting minor effect.

Table 3

QTLs associated with rice false smut (RFS) disease detected by composite interval mapping (CIM)

\begin{tabular}{|c|c|c|c|c|c|c|c|c|c|c|c|}
\hline Traits & QTLs & $\begin{array}{l}\text { Chromo- } \\
\text { some }\end{array}$ & Left marker & Right marker & $\begin{array}{l}\text { Physical } \\
\text { distance } \\
(\mathrm{Kb})^{\mathrm{a}}\end{array}$ & $\begin{array}{l}\text { Genetic } \\
\text { distance }\end{array}$ & $\begin{array}{l}\text { Peak } \\
\text { marker } \\
(\mathrm{cM})^{\mathrm{b}}\end{array}$ & LOD & Additive & $\mathrm{R}^{2}$ & $\begin{array}{l}\text { Favourable } \\
\text { alleles }^{c}\end{array}$ \\
\hline \multirow[t]{2}{*}{ IP/plant } & qRFSr5.3 & 5 & C5.4852660 & C5.4888145 & 35.485 & $\begin{array}{l}102.6- \\
106.9\end{array}$ & 104.8 & 3.3 & -2.6 & 9.3 & PR116 \\
\hline & qRFSr7.1 & 7 & C7.13373853 & C7.13369043 & 4.811 & $\begin{array}{l}106.1- \\
113.2\end{array}$ & 111.6 & 3.2 & 2.8 & 8.9 & RYT2668 \\
\hline TSB/panicle & qRFSr9.1 & 9 & C9.8029326 & C9.9023440 & 994.114 & $\begin{array}{l}48.9- \\
51.2\end{array}$ & 50 & 6.2 & 3.0 & 20.6 & RYT2668 \\
\hline \multirow[t]{4}{*}{ Score } & qRFSr2.2 & 2 & C2.33882274 & C2.33796392 & 85.880 & $0.9-2.5$ & 1.2 & 3.9 & -0.4 & 11.0 & PR116 \\
\hline & qRFSr4.3 & 4 & C4.31529767 & C4.31393008 & 136.759 & $\begin{array}{l}101.4- \\
102.2\end{array}$ & 102.1 & 3.5 & 0.4 & 8.9 & RYT2668 \\
\hline & qRFSr5.4 & 5 & C5.1021716 & C5.2489245 & 1467.529 & $\begin{array}{l}132.9- \\
138.0\end{array}$ & 135.8 & 3.0 & -0.4 & 8.0 & PR116 \\
\hline & qRFSr7.2 & 7 & C7.13373853 & C7.13369043 & 4.811 & $\begin{array}{l}106.1- \\
113.2\end{array}$ & 111.6 & 5.1 & 0.5 & 14.2 & RYT2668 \\
\hline \multicolumn{12}{|c|}{ a Physical position was determined on the basis of Nipponbare-reference-IRGSP-1.0 } \\
\hline \multicolumn{12}{|c|}{ b Value showed the position of peak marker } \\
\hline \multicolumn{12}{|c|}{ c Alleles are inherited from the mentioned parents } \\
\hline
\end{tabular}

Stable QTLS

QTL analysis was also extended for each trait observed in 2013, 2015 and 2016 separately to determine the stability of QTLs across the season. A total of twenty-four QTLs were mapped on chromosome 1, 2, 3, 4, 6, 7, 9, 11, and 12 (Supplementary table 3). However, QTLs on chromosome 1, 3, 6, 11, and 12 were mapped for the first time when QTL analysis was performed separately but not detected in the analysis of mean data of all seasons. The QTLs on chromosome 2, 4, 7, 9, 11 and 12 were highly consistent and detected for multiple traits across the seasons. Among them, QTLs on chromosome 2 , 4,7 , and 9 were detected in analysis of mean data as well. QTLs on chromosome 1, 3 and 6 were highly unstable which were detected only once for at least one trait.

Analysis of ORFs underlying the QTLs

Based on the physical position of linked SNP markers, the physical map of the Nipponbare reference-IRGSP-1.0 pseudomolecule was searched for the ORFs. The physical intervals of all the QTLs were ranged from $4.811 \mathrm{~Kb}$ to $1467.529 \mathrm{~Kb}$ (Table 3). The detailed list of ORF predicted in the QTL intervals was presented in supplementary table 4. The ORFs were analyzed for all the QTLs except $q R F S r 5.4$ due to larger chromosomal region (1.467 Mb). The qRFSr5.3 affecting IP/plant was spanned in $35.485 \mathrm{~Kb}$ regions containing six genes. Of which, three genes LOC_05g08810, LOC_05g08840, and LOC_05g08850 encode phosphotidylinositol-3-kinase, DnaK protein, and cytochrome P450, respectively and rest three genes encode expressed proteins. Another QTL qRFSr7.1 affecting IP/plant harbours one ORF (LOC_Os07g23690) encoding a root cap protein spanned in the 4.811 Kb regions of the interval. The QTL qRFSr7.1 was found highly stable across the crop seasons that share the genomic location with $q R F S r 7.2$ responsible for score. The qRFSr9. 1 affecting TSB/panicle spanned in $994.114 \mathrm{~Kb}$ regions on chromosome 9 harbouring a total of 116 ORFs. Of which, three genes (LOC_Os09g14010, LOC_Os09g14060, and LOC_Os09g14100) encode RPS2-type disease resistance proteins and one gene (LOC_0s09g14490) encodes a toll interleukin-1 receptor (TIR)-nucleotide binding sites (NBS) domain-containing disease resistance protein (Table 4). Additionally, on chromosome 9 QTLs for IP/plant and TSB/panicle were also observed on the short arm during the crop season 2016 . This region spans a $102.7 \mathrm{~Kb}$ interval harbouring 11 ORFs including one functional protein-coding ORF, LOC_Os09g12150 encoding an F-Box domain-containing protein. Similarly, the qRFSr2.2 locus affecting score spanned in $85.880 \mathrm{~Kb}$ regions on the chromosome 2 harboring 16 ORFs that belong to diverse biological functions. 
The genomic region of the locus qRFSr4.3 contains 16 ORFs spanned in $136.759 \mathrm{~Kb}$ regions including one disease resistance gene (LOC_Os04g52780) encodes a leucine-rich repeats (LRR) receptor protein kinase.

Table 4

Putative disease resistance genes identified within the QTL intervals conferring

\begin{tabular}{|lll|}
\hline QTLs & Locus Id & Encoded protein \\
\hline qRFSr4.3 & LOC_04g52780 & Leucine-rich repeat receptor protein kinase \\
qRFSr9.1 & LOC_Os09g14010 & Disease resistance protein- RPS2 \\
& LOC_0s09g14060 & Disease resistance protein- RPS2 \\
\cline { 2 - 3 } & LOC_Os09g14100 & Disease resistance protein- RPS2 \\
\hline LOC_Os09g14490 & TIR-NBS type disease resistance protein \\
\hline
\end{tabular}

Some QTLs were observed only in either of the Kharif crop season and analysed for the putative ORFs (Supplementary table 3 ). Locus 11 was mapped in the year 2015 at $94.5 \mathrm{cM}$ and $266.4 \mathrm{cM}$ for TSB/plant and score, respectively. This region ( $94.5 \mathrm{cM})$ spanned in $377.7 \mathrm{~Kb}$ intervals containing 65 ORFs including four disease resistance genes. Among them, four genes, LOC_Os11g17014 encodes a NB-ARC domain containing protein, LOC_Os11g17110 and LOC_Os11g17120 encode a RPM1-type disease resistance protein and LOC_Os11g17110 encodes a stripe rust resistance protein-Yr10. Two loci were mapped on chromosome 12 for TSB/panicle and score. Both the loci were flanked by same markers spanned in the 655.8 $\mathrm{Kb}$ regions. Therefore, QTLs mapped on chromosome 12 was considered as single locus that contains 91 ORFs including LOC_Os12g17480 encodes a MLA12, LOC_Os12g17490 encodes a stripe resistance protein-Yr10 and LOC_Os12g18360 and LOC_Os12g18374 encode NB-ARC domain containing proteins.

Analysis of structural variations in the QTL regions

Structural variations (SV) and presence and absence variations (PAV) in the QTL regions were analyzed among RILs including parents. A total of 2362 genome-wide insertion and deletion markers (InDels) were found with reference genome. Of which, 1410 InDels were polymorphic between two parents (Supplementary table 5). Among them, 34 InDels were identified within seven QTLs. After careful examination, we found that 2 InDels C9.8620154 (TA/TAA allele) and C9.8760422 (ATTTT/ATTT allele) within qRFSr9. 1 and one InDel C5.1169072 (TTG/T allele) within qRFSr5.4 were co-segregate with the trait TSB/panicle and score, respectively (Supplementary table 5). The physical location of the InDel marker C9.8620154 was analyzed in rice genome annotation project. This marker was located at $44.9 \mathrm{~Kb}$ downstream from a TIR-NBS domain containing disease resistance protein (LOC_Os09g14540). Similarly, SNP C9.8541647 was located at just 22.6 Kb upstream of the LOC_Os09g14540. Additionally, 138 SNPs were polymorphic between two parents within the QTL regions. Among them, 32 SNPs were co-segregated with different component traits of false smut disease (Supplementary table 5). Based on the physical location, C9.8149063 and C9.8518466 was flank the cluster of three disease resistance genes (LOC_Os09g14010, LOC_Os09g14060, and LOC_Os09g14100) within the qRFSr9. 1 locus. These two SNP markers C9.8149063 and C9.8518466 cover $369.4 \mathrm{~Kb}$ in the rice genome. These InDels and SNPs can be converted into PCR-based markers for efficient transfer of the genes using marker-assisted breeding (MAB). The sequence information of these InDels and SNPs was given in supplementary table 6.

\section{Discussion}

\section{QTLs conferring RFS resistance}

The outcome of the present study illustrated promising QTLs associated with resistance to the rice false smut disease along with disease resistance genes which could be effectively utilized in rice breeding programs after further validation. A total of seven QTLs mapped on chromosome 2, 4, 5, 7, and 9 for resistance to rice false smut disease. The QTLs on chromosomes 2, 4, and 5 are consistent with the earlier reports (Zhou et al. 2014; Li et al. 2011; Andargie et al. 2018, Han et al. 2020) whereas the QTLs on chromosome 7 and 9 were detected for the first time in this report. Zhou et al. (2004) reported ten quantitative resistance loci (QRLs) on eight rice chromosomes using an introgression lines derived from RFS resistant parent Lemont and susceptible parent Teqing. Among them, two novel QRLs qFSR-2-4 and qFSR-4-1 were mapped on chromosome 2 and 4, respectively. The qFSR-2-4 was mapped between RM324 and RM145 on chromosome 2 whereas qFSR-4-1 was mapped between RM307 and RM401 on chromosome 4 . Li et al. (2011) was also identified QTLs on chromosome 2 and 4 for RFS resistance using a RIL population derived from the cross between IR28 as a donor and Daguandao. Of which, QTL detected on chromosome 4 was mapped between RM417 and RM280 while QTL on chromosome 2 overlapped the previously mapped QTL qFSR-2-4. More recently, QTLs associated with resistance to false smut on chromosome 2 and 4 were detected in RIL population derived from MR183-2/08R2394 cross. The qFsr2-1 was mapped between RM13400 and RM13439 explaining 6.9\% phenotypic variance whereas qFsr4-1 was detected between RM16757 and RM16770 with 1.8\% phenotypic variance (Han et al. 2020). Han et al. (2020) mapped a novel larger effect QTL qFsr8-1 in 524 Kb region flanked by RM22507 and RM22540 on chromosome 8. Interestingly, we did not detect any QTL on chromosome 8. Andargie et al. (2018) mapped two QTLs qRFSr5. 1 and qRFSr5.2 on chromosome 5. The qRFSr5.1 detected between markers RM18451 and RM65 at 2.8 LOD whereas qRFSr5.2 was mapped between RM72 and RM75 at 6.8 LOD. Of these QTLs, qRFSr5.1 account for $7.3 \%$ phenotypic variance contributed from donor parent IR28 and considered as a minor effect QTL. However, qRFSr5.2 was a major QTL inherited from recipient parent 
displaying $16.4 \%$ phenotypic variance. Based on the previous reports, rice false smut is controlled by combination of major and minor QTLs. A comparison of these previously reported QTLs with the genetic positions of ours revealed that they are fairly close indicating the presence of 'hot-spot' region of disease resistance genes. This is also supported by the fact that the numerous disease resistance genes controlling sheath blight, brown spot, bacterial seedling rot, bacterial grain rot, bacterial blight, blast, and black streak dwarf virus resistance genes were reported on chromosome $3,4,6,11$, and 12 (Sato et al. 2015; Pinson et al. 2010; Zhou et al. 2015). In the rice chromosome 11, more than 13 loci for bacterial blight resistance and 27 loci for blast resistance have been mapped which mostly belong to the R genes (resistance genes) family (Vikal and Bhatia 2016, Ashikani et al. 2016). Transfer of these gene clusters as a unit into elite cultivars could be helpful for breeding broad-spectrum disease resistance across the different environment, different mapping population and variable pathogenic races.

\section{Disease resistance genes control the RFS resistance in rice}

To the best of author's knowledge, only two reports published that showed the identification of disease resistance genes ( $R$ genes) against RFS in rice (Han et al. 2020, Qiu et al. 2020). In this study, we also have reported identification of putative disease resistance genes conferring resistance to rice false smut. Analysis of physical interval of qRFSr 9.1 accounting for the largest phenotypic variance revealed four open reading frames including RPS2disease resistance proteins and the TIR-NBS-LRR-type disease resistance protein. RPS2 is a major class of resistance genes encoding a NBS-LRR domain-containing protein in Arabidopsis which confers broad-spectrum resistance against Pseudomonas syringae (Bent et al. 1994; Mindrinos et al. 1994). RPS2 is highly similar to the $\mathrm{N}$ gene conferring resistance to the tobacco mosaic virus (TMV) in tobacco (Whitham et al. 1994$)$ and the $L 6$ gene conditioning resistance to flax rust fungus Melampsora lini in flax (Lawrence et al. 1995). Based on the sequence similarity of the $\mathrm{Ngene}$ of tobacco and RPS2 of Arabidopsis, a homologous disease resistance gene has been cloned in soybean (Yu et al. 1996). In rice, disease resistance gene homologues were identified from high yielding variety IR64 using NBS-LRR domain of Arabidopsis RPS2 gene as a heterologous hybridization probe (llag et al. 2000). A highly consistent QTL detected on chromosome 11 across multiple traits and seasons was spanned within $377.7 \mathrm{~Kb}$ regions harbors four putative candidate genes encoding for RPM1, stripe rust resistance-Yr10, and other classes of NBS-LRR domain-containing disease resistance proteins (Supplementary table 3). The RPM1 belongs to a non-TIR class of NBS-LRR domain-containing protein in Arabidopsis (Grant et al. 1995; McDowell et al. 1998). The functional homolog of the Arabidopsis RPM1 gene has been cloned from bean and pea (Dangl et al. 1992). Leister et al. (1998) used the conserve sequences of NBS-LRR domain from dicot species to isolate the R gene homologues from two monocot species rice and barley revealed exceptional sequence diversity and copy number variations. In the genomic region of the locus detected on chromosome 12 , four putative candidate genes were predicted that encode MLA12, stripe resistance protein-Yr10 and NB-ARC domain-containing disease resistance proteins (Supplementary table 3). In rice, several R genes containing NBS-LRR domain have been well characterized that confer resistance to blast and bacterial leaf blight diseases (Yoshimura et al. 1998; Sun et al. 2004; Qu et al. 2006). Finally, the identification of R genes controlling RFS demonstrated the feasibility for map-based cloning provides an insight to understand the complex plant-pathogen interactions. The candidate genes analysis offers a great opportunity for developing perfect functional markers for marker-assisted selection for breeding false smut resistant rice varieties.

In conclusion, we identified potential chromosomal regions carrying favourable alleles for resistance against false smut disease of rice. Most of them are co-localized with the QTLs associated with broader disease resistance in rice and hence could be targeted for deployment in breeding programs. A large effect QTL, qRFSr9.1 was identified on chromosome 9 spanned in $994.114 \mathrm{~Kb}$ region harbouring four disease resistance genes but it will be necessary to narrow the QTL confidence intervals prior to its use. The SNP markers closely linked to the $q R F S r 9.1$ can be converted into breeder-friendly PCR based markers which will facilitate the identification of resistant line at an early stage of development and transfer into elite cultivars through marker-assisted selection (MAS). A large number of genes associated with plant defence response were identified in this study which needs to be validated using functional genomics approaches. This information could be helpful for cloning and characterization of RFS resistance genes and understanding the mechanism of host-pathogen interaction in rice.

\section{Declarations}

\section{Compliance with Ethical Standards}

\section{Author contributions}

KS, KN and JSL conceived the experiment. GSM, RK and RK developed the RIL population. IK, JSL, AK, PK, AB and GK helped in the phenotyping of false smut disease. KN, KK, AK analysed the genotypic data. KN and KK wrote the manuscript. AK, YV and KS critically edited the manuscript.

\section{Funding}

The Authors are grateful to the ICAR for funding under the Project 'Incentivizing research in agriculture projectIV-Molecular genetic analysis of resistance/tolerance to different stress (Rice)' CS/F.No. 16-8/17-IA IV.

\section{Conflict of interest}

Kumari Neelam declares no conflict of interest.

Kishor Kumar declares no conflict of interest.

Amandeep Kaur declares no conflict of interest. 
Amit Kishore declares no conflict of interest.

Pavneet Kaur declares no conflict of interest

Ankita Babbar declares no conflict of interest.

Gurwinder Kaur declares no conflict of interest.

Ishwinder Kamboj declares no conflict of interest.

Jagjeet Singh Lore declares no conflict of interest.

Yogesh Vikal declares no conflict of interest.

G.S. Mangat declares no conflict of interest.

Rupinder Kaur declares no conflict of interest.

Renu Khanna declares no conflict of interest.

Kuldeep Singh declares no conflict of interest.

\section{Ethical approval}

This article does not contain any studies with human participants or animals performed by any of the authors.

\section{Data availability}

All large-scale data related to this study is available in this manuscript as supplementary tables.

\section{References}

1. Andargie M, Li J (2016) Arabidopsis thaliana: A model host plant to study plant-pathogen interaction using rice false smut isolates of Ustilaginoidea virens. Front Plant Sci 7:192. https://doi.org/10.3389/fpls.2016.00192

2. Andargie M, Li L, Feng A, Zhu X, Li J (2018) Mapping of the quantitative trait locus (QTL) conferring resistance to rice false smut disease. Curr Plant Biol 15:38-43. https://doi.org/10.1016/j.cpb.2018.11.003

3. Ashizawa T, Takahashi M, Arai M, Arie T (2012) Rice false smut pathogen, Ustilaginoidea virens, invades through small gap at the apex of a rice spikelet before heading. J Gen Plant Pathol 78:255-259. https://doi.org/10.1007/s10327-012-0389-3

4. Ashkani S, Rafii MY, Shabanimofrad M, Ghasemzadeh A, Ravanfar SA, Latif MA (2016) Molecular progress on the mapping and cloning of functional genes for blast disease in rice (Oryza sativa L.): Current status and future considerations. Crit Rev Biotechnol 36:353-367. https://doi.org/10.3109/07388551.2014.961403.

5. Baird NA, Etter PD, Atwood TS, Currey MC, Shiver AL, Lewis ZA., et al. (2008) Rapid SNP discovery and genetic mapping using sequenced RAD markers. PLoS ONE 3:e3376. https://doi.org/10.1371/journal.pone.0003376

6. Bent AF, Kunkel BN, Dahlbeck D, Brown KL, Schmidt R, Giraudat J, et al. (1994) RPS2 of Arabidopsis thaliana: A leucine-rich repeat class of plant disease resistance genes. Science 265:1856-1860. https://doi.org/10.1126/science.8091210

7. Brooks SA, Anders MM, Yeater KM (2009) Effect of cultural management practices on the severity of false smut and kernel smut of rice. Plant Dis 93:1202-1208. https://doi.org/10.1094/PDIS-93-11-1202

8. Chaudhari AK, Rakholiya KB, Baria TT (2019) Screening of Rice Cultivars against False Smut [Ustilaginoidea virens (Cooke) Takahashi] of Rice. Int J Curr Microbiol Appl Sci 8:2786-2793. https://doi.org/10.20546/ijcmas.2019.806.336

9. Churchill GA, Doerge RW (1994) Empirical threshold values for quantitative trait mapping. Genetics 138:963-971. https://doi.org/10.1007/s11703007-0022-y

10. Dangl JL, Ritter C, Gibbon MJ, Mur LA, Wood JR, Goss S, et al. (1992) Functional homologs of the arabidopsis RPM1 disease resistance gene in bean and pea. Plant Cell 4:1359-1369. https://doi.org/10.2307/3869508

11. Fan J, Guo XY, Li L, Huang F, Sun WX, Li Y, et al. (2015) Infection of Ustilaginoidea virens intercepts rice seed formation but activates grain-fillingrelated genes. J Integr Plant Biol 57:577-590. https://doi.org/10.1111/jipb.12299

12. Fan J, Yang J, Wang YQ, Li GB, Li Y, Huang F, et al. (2016) Current understanding on Villosiclava virens, a unique flower-infecting fungus causing rice false smut disease. Mol Plant Pathol 17:1321-1330. https://doi.org/10.1111/mpp.12362

13. Grant MR, Godiard L, Straube E, Ashfield T, Lewald J, Sattler A, et al. (1995) Structure of the Arabidopsis RPM1 gene enabling dual specificity disease resistance. Science 269:843-846. https://doi.org/10.1126/science.7638602 
14. Han Y, Li D, Yang J, Huang F, Sheng H, Sun W (2020) Mapping quantitative trait loci for disease resistance to false smut of rice. Phytopathol Res 2:20. https://doi.org/10.1186/s42483-020-00059-6

15. Ilag LL, Yadav RC, Huang N, Ronald PC, Ausubel FM (2000) Isolation and characterization of disease resistance gene homologues from rice cultivar IR64. Gene 255:245-255. https://doi.org/10.1016/S0378-1119(00)00333-4.

16. IRRI (2002) Standard Evaluation System for Rice (SES). Los Banos. Philippines: International Rice Research Institute (IRRI). Pp. 14.

17. Kaur Y, Lore JS, Pannu PPS (2018) Development of screening technique for artificial creation of false smut in rice. J Appl Nat Sci 10:253-257. https://doi.org/10.31018/jans.v10i1.1613

18. Ke Y, Deng H, Wang S (2017) Advances in understanding broad-spectrum resistance to pathogens in rice. Plant J 90:738-748. https://doi.org/10.1111/tpj.13438

19. Koiso Y, Li Y, Iwasaki S, Kobayashi T, Sonoda R, Fujita Y, et al. (1994) Ustiloxins, antimitotic cyclic peptides from false smut balls on rice panicles caused by ustilaginoidea virens. J Antibiot 47:765-773. https://doi.org/10.7164/antibiotics.47.765

20. Kumari S, Kumar J (2015) Evaluation of yield losses and management practices of false smut in rice (Oryza sativa). Indian phytopathol 68: $45-49$.

21. Ladhalakshmi D, Laha GS, Singh R, Karthikeyan A, Mangrauthia SK, Sundaram RM, et al. (2012) Isolation and characterization of Ustilaginoidea virens and survey of false smut disease of rice in India. Phytoparasitica 40:171-176. https://doi.org/10.1007/s12600-011-0214-0

22. Lawrence GJ, Finnegan EJ, Ayliffe MA, Ellis JG (1995) The $L 6$ gene for flax rust resistance is related to the Arabidopsis bacterial resistance gene RPS2 and the tobacco viral resistance gene N. Plant Cell 7:1195-1206. https://doi.org/10.1105/tpc.7.8.1195

23. Li YS, Huang SD, Yang J, Wang CL (2011) Analysis of Quantitative Trait Loci for Resistance to Rice False Smut. Acta Agron Sin 37: $778-783$.

24. Li YS, Zhu Z, Zhang YD, Zhao L, Wang CL (2008) Genetic analysis of rice false smut resistance using mixed major genes and polygenes inheritance model. Acta Agron Sin 34:1728-1733. https://doi.org/10.1016/S1875-2780(09)60007-9

25. Li Y, Koiso Y, Kobayashi H, Hashimoto Y, Iwasaki S (1995) Ustiloxins, new antimitotic cyclic peptides: Interaction with porcine brain tubulin. Biochem Pharmacol 49:1367-1372. https://doi.org/10.1016/0006-2952(95)00072-8

26. Lore JS, Pannu PPS, Jain J, Hunjan MS, Kaur R, Mangat GS (2013) Susceptibility of rice hybrids and inbred cultivars to false smut under field conditions. Indian Phytopath 66:397-399.

27. Lorieux M (2012) MapDisto: fast and efficient computation of genetic linkage maps. Mol Breed 30:1231-1235.

28. Ludueña RF, Roach MC, Prasad V, Banerjee M, Koiso Y, Li Y, et al. (1994) Interaction of ustiloxin a with bovine brain tubulin. Biochem Pharmacol 47:1593-1599. https://doi.org/10.1016/0006-2952(94)90537-1

29. McDowell JM, Dhandaydham M, Long TA, Aarts MG, Goff S, Holub EB, et al. (1998) Intragenic recombination and diversifying selection contribute to the evolution of downy mildew resistance at the RPP8 locus of Arabidopsis. Plant Cell 10:1861-1874. https://doi.org/10.2307/3870909

30. Mindrinos M, Katagiri F, Yu GL, Ausubel FM (1994) The A. thaliana disease resistance gene RPS2 encodes a protein containing a nucleotidebinding site and leucine-rich repeats. Cell 78:1089-1099. https://doi.org/10.1016/0092-8674(94)90282-8

31. Mizobuchi R, Fukuoka S, Tsushima S, Yano M, Sato H (2016) QTLs for Resistance to Major Rice Diseases Exacerbated by Global Warming: Brown Spot, Bacterial Seedling Rot, and Bacterial Grain Rot. Rice 9:23. https://doi.org/10.1186/s12284-016-0095-4.

32. Nakamura KI, Izumiyama N, Ohtsubo KI, Koiso Y, Iwasaki S, Sonoda R, et al. (1994) "Lupinosis"-Like lesions in mice caused by ustiloxin, produced by Ustilaginoieda virens: A morphological study. Nat Toxins 2:22-28. https://doi.org/10.1002/nt.2620020106

33. Pannu PPS, Thind TS, Goswami S (2010) Standardization of technique for artificial creation of false smut of rice and its management. Indian Phytopath 63: 234-235.

34. Pinson SRM, Shahjahan AKM, Rush MC, Groth DE (2010) Bacterial panicle blight resistance QTLs in rice and their association with other disease resistance loci and heading date. Crop Sci 50:1287-1297. https://doi.org/10.2135/cropsci2008.07.0447

35. Qiu J, Shuai M, Yizhen D, Shiwen H, Yanjun K (2019) Ustilaginoidea virens: A fungus infects rice flower and threats world rice production. Rice Sci 26:199-206. https://doi.org/10.1016/j.rsci.2018.10.007

36. Qiu J, Lu F, Wang H, Xie J, Wang C, Liu Z, et al. (2020) A candidate gene for the determination of rice resistant to rice false smut. Mol Breeding 40:105. https://doi.org/10.1007/s11032-020-01186-w

37. Qu S, Liu G, Zhou B, Bellizzi M, Zheng L, Dai L, et al. (2006) The broad-spectrum blast resistance gene Pi9 encodes a nucleotide-binding siteleucine-rich repeat protein and is a member of a multigene family in rice. Genetics 172:1901-1914. https://doi.org/10.1534/genetics.105.044891

38. Rani R, Sharma VK, Lore JS, Pannu PPS, Kaur Y (2016) Screening of rice germplasm against Ustilaginoidea virens, the incitant of false smut. Agric Res J 53:134-137. https://doi.org/10.5958/2395-146x.2016.00026.0

39. Rush MC, Shahjahan AKM, Jones JP, Groth DE (2000) Outbreak of False Smut of Rice in Louisiana. Plant Dis 84:100. https://doi.org/10.1094/pdis.2000.84.1.100d

40. Sato H, Matsumoto K, Ota C, Yamakawa T, Kihara J, Mizobuchi R (2015) Confirming a major QTL and finding additional loci responsible for field resistance to brown spot (Bipolaris oryzae) in rice. Breed Sci 65:170-175. https://doi.org/10.1270/jsbbs.65.170.

41. Shan T, Sun W, Liu H, Gao S, Lu S, Wang M, et al. (2012) Determination and analysis of ustiloxins A and B by LC-ESI-MS and HPLC in false smut balls of rice. Int J Mol Sci 13:11275-11287. https://doi.org/10.3390/ijms130911275 
42. Sun X, Cao Y, Yang Z, Xu C, Li X, Wang S, et al. (2004) Xa26, a gene conferring resistance to Xanthomonas oryzae pv. oryzae in rice, encodes an LRR receptor kinase-like protein. Plant J 37:517-527. https://doi.org/10.1046/j.1365-313X.2003.01976.X

43. Tang YX, Jin J, Hu DW, Yong ML, Xu Y, He LP (2013) Elucidation of the infection process of Ustilaginoidea virens (teleomorph: Villosiclava virens) rice spikelets. Plant Pathol 62:1-8. https://doi.org/10.1111/j.1365-3059.2012.02629.x

44. Thomson MJ (2015) High-throughput SNP genotyping to accelerate rice improvement. Plant Breed Biotech 2:195-212. https://doi.org/10.9787/PBB.2014.2.3.195

45. Vikal Y, Bhatia D (2017) “Genetics and Genomics of Bacterial Blight Resistance in Rice," in Advances in International Rice Research (London UK: InTechOpen) https://doi.org/10.5772/67361.

46. Voorrips RE (2002) MapChart: software for the graphical presentation of linkage maps and QTLs. J Hered 93:77-78. https://doi.org/10.1093/jhered/93.1.77

47. Wang S, Basten CJ, Zeng ZB (2011) Windows QTL Cartographer 2.5. Department of Statistics, North Carolina state University, Raleigh

48. Wang WM, Fan J, Jeyakumar JMJ (2019) "Rice false smut: an increasing threat to grain yield and quality", in Protecting Rice Grains in the PostGenomic Era, ed. Y. Jia (London UK: IntechOpen), 89-108. https://doi.org/10.5772/intechopen.84862

49. Whitham S, Dinesh-Kumar SP, Choi D, Hehl R, Corr C, Baker B (1994) The product of the tobacco mosaic virus resistance gene N: Similarity to toll and the interleukin-1 receptor. Cell 78:1101-1015. https://doi.org/10.1016/0092-8674(94)90283-6

50. Xu JL, Xue QZ, Luo LJ, Li ZK (2002) Preliminary report on quantitative trait loci mapping of false smut resistance using near-isogenic introgression lines in rice. Acta Agric Zhejiang 14: 14-19.

51. Yang C, Li L, Feng A, Zhu X, Li J (2014) Transcriptional profiling of the responses to infection by the false smut fungus Ustilaginoidea virens in resistant and susceptible rice varieties. Can J Plant Pathol 36:377-388. https://doi.org/10.1080/07060661.2014.927925

52. Yoshimura S, Yamanouchi U, Katayose Y, Toki S, Wang ZX, Kono I, et al. (1998) Expression of Xa1, a bacterial blight-resistance gene in rice, is induced by bacterial inoculation. Proc Natl Acad Sci USA 95:1663-1668. https://doi.org/10.1073/pnas.95.4.1663

53. Yu YG, Buss GR, Saghai Maroof MA (1996) Isolation of a superfamily of candidate disease-resistance genes in soybean based on a conserved nucleotide-binding site. Proc Natl Acad Sci USA 93:11751-11756. https://doi.org/10.1073/pnas.93.21.11751

54. Zhang Y, Zhang K, Fang A, Han Y, Yang J, Xue M, et al. (2014) Specific adaptation of Ustilaginoidea virens in occupying host florets revealed by comparative and functional genomics. Nat Commun 5:3849. https://doi.org/10.1038/ncomms4849

55. Zhou T, Du L, Wang L, Wang Y, Gao C, Lan Y, et al. (2015) Genetic analysis and molecular mapping of QTLs for resistance to rice black-streaked dwarf disease in rice. Sci Rep 5:10509. https://doi.org/10.1038/srep10509.

56. Zhou YL, Xie XW, Zhang F, Wang S, Liu XZ, Zhu LH, et al. (2014) Detection of quantitative resistance loci associated with resistance to rice false smut (Ustilaginoidea virens) using introgression lines. Plant Pathol 63:365-372. https://doi.org/10.1111/ppa.12091

\section{Figures}




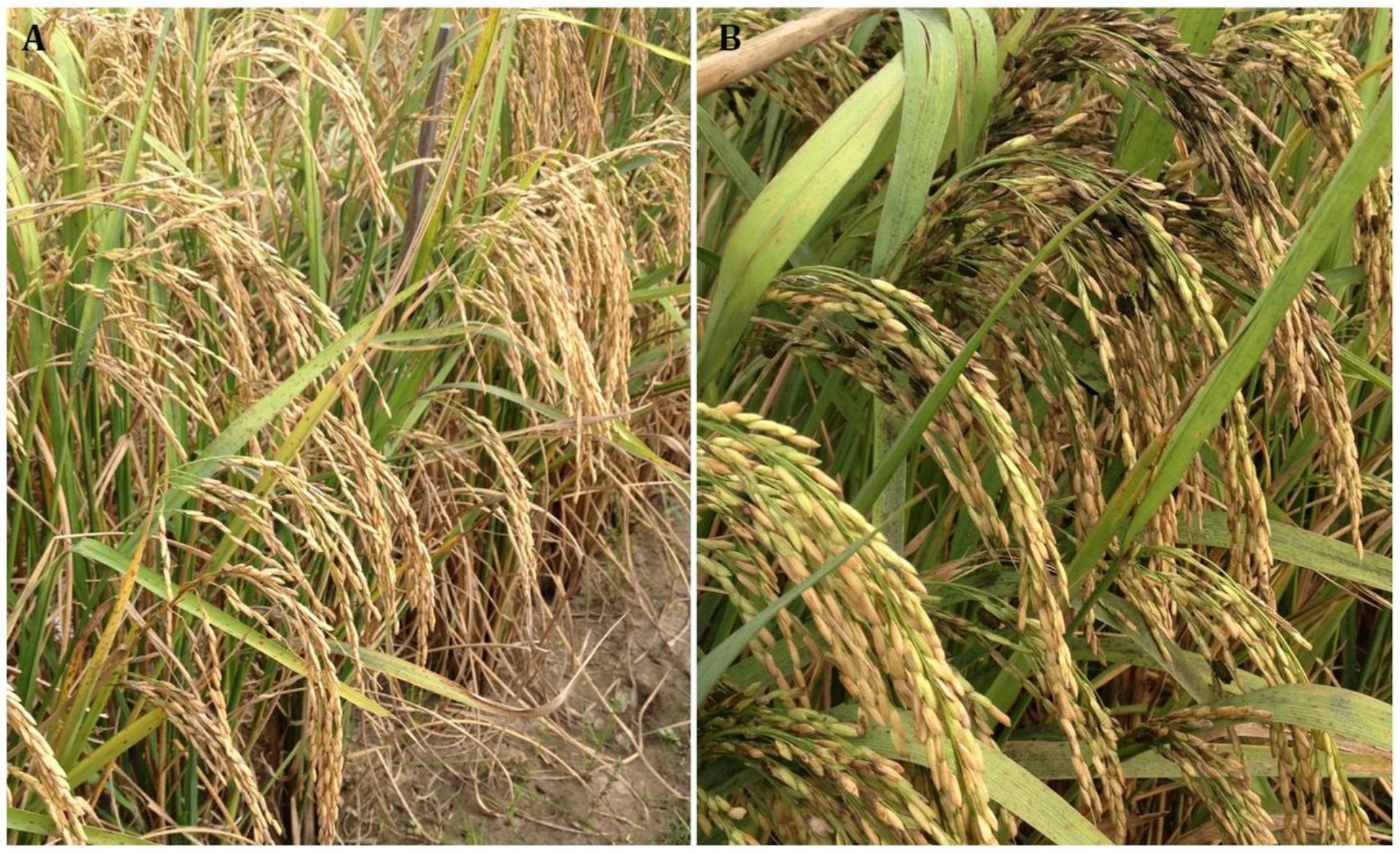

Figure 1

Rice false smut disease symptoms appeared on resistant parent RYT2668 (A) and susceptible parent PR116 (B). 
Chr02

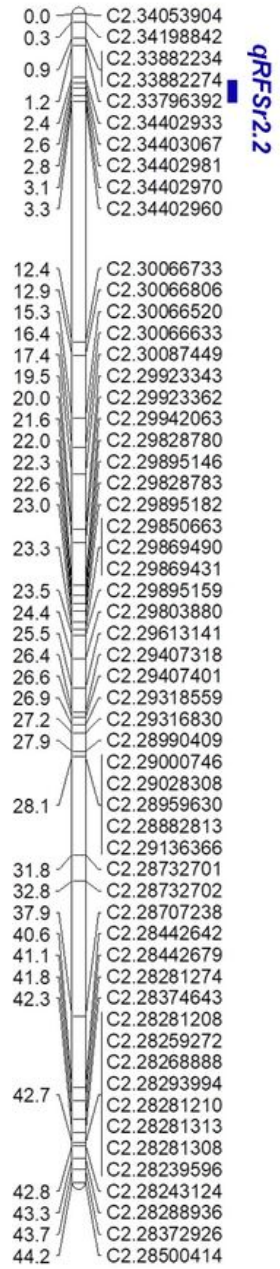

Chr04

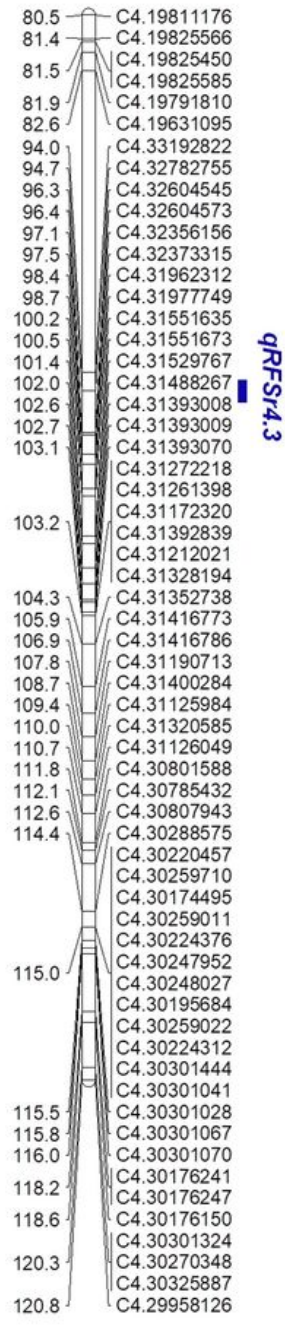

Chr05

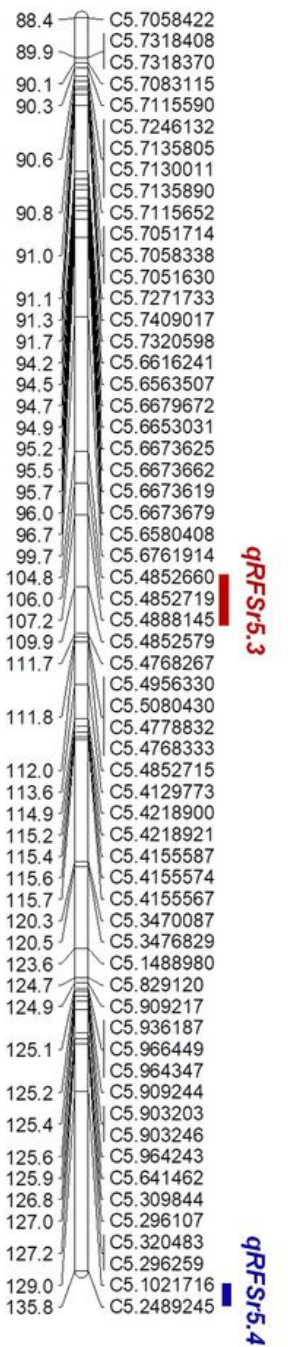

Chr07

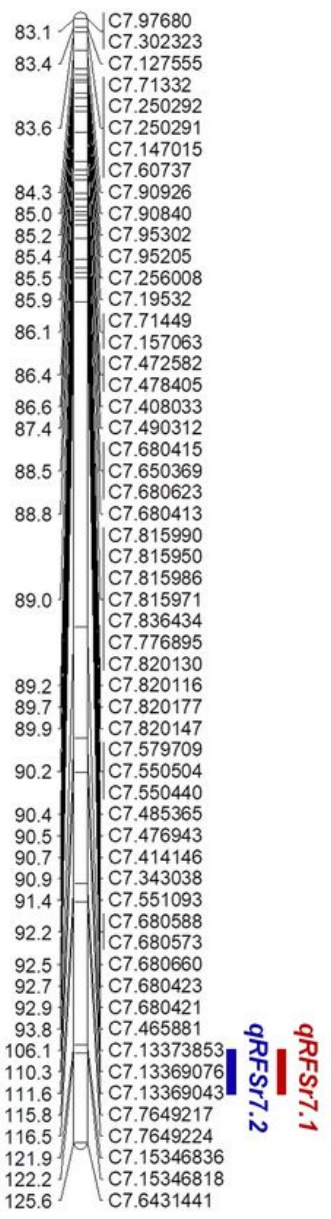

Chr09

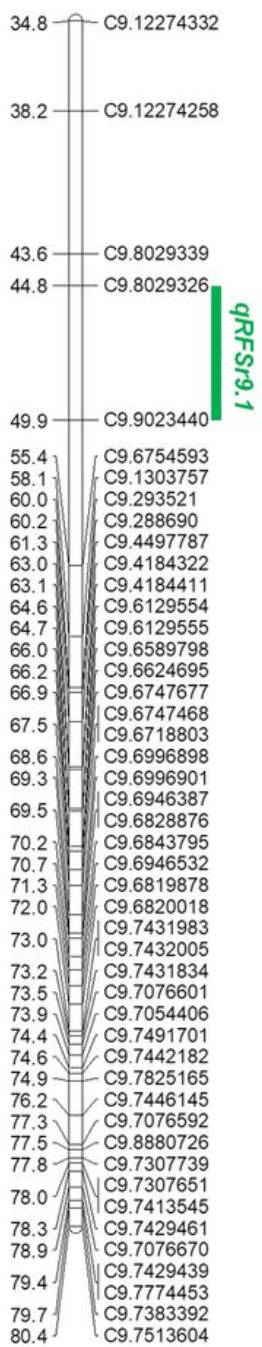

Figure 2

Location of the false smut resistant QTLs on the partial linkage map of rice. Positions of the markers (cM) are shown on the left whereas the markers are shown on the right of the chromosome bars. The QTLs controlling infected panicles (IP)/plant are marked by red bars, QTL responsible for total smut balls (TSB)/panicle are indicated by green bar and the QTLs affecting score are shown by blue bars.

\section{Supplementary Files}

This is a list of supplementary files associated with this preprint. Click to download.

- Supp.Fig1.Geneticmap.pdf

- Supp.Table1Genotypicdata.xlsx

- Supp.Table2Linkagemapdata.xlsx

- Supp.Table3QTLinformationandcandidategenes.xlsx

- Supp.Table4Candidategene.xlsx

- Supp.Table5.xlsx

- Supp.Table6.xlsx 